\title{
Microwave Treatment of Soil for Weed and Pathogen Control
}

ISSN: 2640-9208

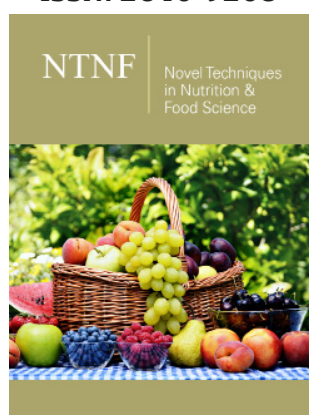

*Corresponding author: Graham Brodie, Faculty of Veterinary and Agricultural Sciences, The University of Melbourne, Australia

Submission: 監June 28, 2021

Published: 䣬July 15, 2021

Volume 6 - Issue 1

How to cite this article: Graham Brodie, Dorin Gupta, Muhammad Jamal Khan Microwave Treatment of Soil for Weed and Pathogen Control. Nov Tech Nutri Food Sci. 6(1). NTNF. 000629. 2021. DOI: 10.31031/NTNF.2021.06.000629

Copyright@ Graham Brodie. This article is distributed under the terms of the Creative Commons Attribution 4.0 International License, which permits unrestricted use and redistribution provided that the original author and source are credited.

\section{Graham Brodie*, Dorin Gupta and Muhammad Jamal Khan}

Faculty of Veterinary and Agricultural Sciences, The University of Melbourne, Australia

\section{Introduction}

Soil is the foundation of agricultural and horticultural endeavors. The soil solution is a heterogeneous mixture of solids, liquids, gasses, and biological entities. The general health and nutritional status of soil determines the quantity and quality of its biological components, especially the plants that grow in it. The presence of pests and pathogens can impact soil health, leading to significant crop yield losses [1]. Various strategies are used to control pests and pathogens; however, modern agriculture has largely resorted to chemical control strategies.

Chemical pest control has been a blessing; however, the development of chemical resistance in the target pests and pathogens has been inevitable [2,3]. Various alternative control strategies have been explored, including soil heating. Soil steaming [4-6] and surface heating through flaming [7] or solarization have been explored; however, soil is a relatively poor conductor of heat [8] and the efficacy of soil heating systems is limited because of this. Microwave heating has also been considered, because microwaves volumetrically interact with materials and generates heat throughout the interaction volume, thus avoiding thermal conduction limits.

\section{Microwaves}

Microwaves are a form of light (electromagnetic energy), with wavelengths between $1 \mathrm{~cm}$ and $1 \mathrm{~m}$ long [9]. These wavelengths are invisible to humans; however, they strongly interact with dipolar molecules and ionic solutions, generating internal heat due to molecular agitation of these molecules in the electromagnetic field [10]. The extent of interaction between an electromagnetic field and a material depends on the material's dielectric properties. Water is of interest to microwave heating because it has quite high dielectric properties at microwave wavelengths [10]. This is enhanced because water is a strong solvent of salts, creating ionic solutions, which greatly increases the loss factor of the dielectric properties [10]; however, the water molecule itself has a strong dipolar moment [11]. In the case of microwave treatment of soil, the water in the soil solution and the biological entities in the soil strongly interreact with the microwave fields to generate heat in the soil.

\section{Microwave Soil Treatment}

The propagation of microwave energy through soil depends upon the gravimetric $\left(\theta_{\mathrm{g}}\right)$ and volumetric $\left(\theta_{v}\right)$ moisture content [12], bulk density [13], organic matter content [14], soil texture [15], and specific heat of the soil [8]. Soil moisture has the most effect on microwave soil heating [16]. The greatest challenge when heating soil, in-situ, is that the microwave energy must be projected into the soil rather than the soil being placed into a microwave oven cavity. Several devices, called applicators $[9,17]$, can be used to apply microwave energy to a semi-infinite solid, like soil. The simplest option is to use an antenna, pointing to the ground [18]. The horn antenna is a very simple structure that has been used for soil heating 
for several decades [18,19]. Horn antennas are effective, but often heat more soil than is necessary for disinfection.

Novel applicator structures have been developed to restrict the application of microwave energy to the surface layers of the soil [20,21]. Slow-wave structures [21] and applicators based on the principle of frustrated total internal reflection [22] create evanescent microwave fields that propagate along the surface of the applicators, but do not penetrate very far into the soil, because of the exponential decay of the evanescent microwave fields. These heat the surface layers of the soil without wasting energy heating deeper layers of soil.

\section{Weed Management}

Davis et al. [23] demonstrated the efficacy of microwave energy for weed management. They developed a prototype system, called the "Zapper" [24], which could treat soil in situ, using a variant on a horn antenna to apply the microwave energy to the soil's surface. To obtain consistent pre-emergent control of both broadleaved weeds and grasses, it was necessary to apply at least 183 $\mathrm{cm}$ ${ }^{2}$. Brodie et al. [25] later confirmed that $185 \mathrm{~J} \mathrm{~cm}^{-2}$ of microwave energy, when applied to moist soil, could effectively kill various Lolium spp. (ryegrasses) seeds to a depth of $5 \mathrm{~cm}$. Treating seeds in dry soil required over $550 \mathrm{~J} \mathrm{~cm}^{-2}$ of microwave energy to kill seeds to a depth of only $2-3 \mathrm{~cm}$ [25].

The energy required to control emerged weeds using a horn antenna is quite variable $\left(77-500 \mathrm{~J} \mathrm{~cm}^{-2}\right)[23,26]$, depending in the species and the height of the horn antenna above the ground. Recent experiments using a $15 \mathrm{~cm}$ wide slow-wave applicator, connected to a $5-\mathrm{kW}$ microwave source, and being towed at an equivalent speed of approximately $0.6 \mathrm{~km} \mathrm{hr}^{-1}\left(17 \mathrm{~cm} \mathrm{~s}^{-1}\right)$, has demonstrated that applying $20 \mathrm{~J} \mathrm{~cm}^{-2}$ of microwave energy can kill most emerged weeds (unpublished).

\section{Effects on Soil Biota}

It has been demonstrated that microwave soil heating has an immediate impact on soil microbial communities [27]. The populations of some species are significantly reduced [28]; however, other species, including nitrifying bacteria and archaea, are relatively unaffected, except at extremely high doses of microwave energy [29-31]. Soil bacterial and fungal community compositions change significantly due to microwave soil treatment and recovery of biological diversity takes more than 4-5 weeks [30]. Recent experiments have demonstrated that microwave soil treatments, with similar intensity necessary to kill weed seeds, significantly reduces a number of soils borne fungal pathogens, including Fusarium spp., Macrophomina phaseolina, and Thielaviopsis basicola (unpublished).

The combination of removal of weed competition and soil disinfection provided by microwave soil treatment results in significant crop yield increases. In field experiments, increases in crop yield of between $18 \%$ and 84\%, compared with the untreated or hand weeded controls, have been observed [1,32]. Pot experiments have demonstrated that a single microwave soil treatment can provide significant crop yield increases over several seasons, with the longest observations spanning three years, so far [33].

\section{Conclusion}

Sustained experimental work has demonstrated that microwave energy can be used to effectively control weeds. Soil heating can inactivate dormant weed seeds, thus preventing germination and emergence; however, soil heating requires high energy inputs to achieve seed lethality. An additional benefit of microwave soil treatment is it potential to sanitise soil by changing the soil bacterial and fungal community profile. Microwave treatment does not sterilise the soil; however, it can reduce the populations of several economically important soil borne pathogens and significantly increase crop yields. Soil sanitation may find its application niche in high value horticulture, where soil fumigation is routinely applied prior to crop establishment. Control of emerged weeds requires far less microwave energy, especially when novel microwave applicators such as the slow-wave and frustrated total internal reflection principles, are adopted in their design.

\section{References}

1. Brodie G, Khan MJ, Gupta D (2019) Microwave soil treatment and plant growth. In: Filho \& Hasanuzzaman (Eds.), Sustainable Crop Production. IntechOpen, Brazil.

2. Harper JL (1956) The evolution of weeds in relation to resistance to herbicides. ( $3^{\text {rd }}$ edn), British Weed Control Conference, Farnham, UK, pp. 5-8.

3. Neve P (2007) Challenges for herbicide resistance evolution and management: 50 years after Harper. Weed Research 47(5): 365-369.

4. Fennimore SA, Goodhue RE (2016) Soil disinfestation with steam: a review of economics, engineering, and soil pest control in California strawberry. International Journal of Fruit Science 16: 71-83.

5. Gay P, Piccarolo P, Aimonino RD, Tortia C (2010) A high efficacy steam soil disinfestation system, part II: Design and testing. Biosystems Engineering 107(3): 194-201.

6. Gay P, Piccarolo P, Aimonino RD, Tortia C (2010) A high efficiency steam soil disinfestation system, part I: Physical background and steam supply optimization. Biosystems Engineering 107(2): 74-85.

7. Ascard J (1998) Comparison of flaming and infrared radiation techniques for thermal weed control. Weed Research 38(1): 69-76.

8. Oyeyemia KD, Sanuade OA, Oladunjoye MA, Aizebeokhai AP, Olaojo AA, et al. (2018) Data on the thermal properties of soil and its moisture content. Data in Brief 17: 900-906.

9. Metaxas AC, Meredith RJ (1983) Industrial microwave heating. Peter Peregrinus, London, UK.

10. Brodie G (2021) Modeling the very broad band dielectric properties of water. Journal of Microwave Power and Electromagnetic Energy 55(1): 80-89.

11. Chaplin M (2007) Water structure and science. London South Bank University, UK.

12. Nelson SO (1996) A review and assessment of microwave energy for soil treatment to control pests. ASABE.

13. Hallikainen MT, Ulaby FT, Dobson MC, Rayes MA, Wu LK (1985) Microwave dielectric behavior of wet soil-part 1: Empirical models and experimental observations. IEEE Transactions on Geoscience and Remote Sensing 23(1): 25-34. 
14. Neill PO, Jackson T (1990) Observed effects of soil organic matter content on the microwave emissivity of soils. Remote Sensing of Environment 31(3): 175-182.

15. brodie G, Ryan C, Lancaster C (2012) Microwave technologies as part of an integrated weed management strategy: A review. International Journal of Agronomy, pp. 1-14.

16. Kabir H, Brodie G, Gupta D, Pang A, Jacob MV, et al. (2020) Measurement and modelling of soil dielectric properties as a function of soil class and moisture content. Journal of Microwave Power and Electromagnetic Energy 54(1): 3-18.

17. Meredith R (1998) Engineers' handbook of industrial microwave heating. The Institute of Electrical Engineers, Stevenage, UK.

18. Spanu M, Fanti A, Lodi MB, Casu S, Desogus F, et al. (2016) Microwave's disinfection of farmland. Journal of Electromagnetic Waves and Applications 30(16): 1-9.

19. Zanche CD, Amista F, Baldoin C, Beria S, Giubbolini L (2003) Design, construction and preliminary tests of a microwave prototype for weed control. Rivista di Ingegneria Agraria 34(2): 31-38.

20. Brodie G, Pchelnikov Y, Torgovnikov G (2018) Experimental study of microwave slow wave comb applicators for timber treatment at frequencies 2.45 and $0.922 \mathrm{GHz}$. Journal of Materials Science and Engineering with Advanced Technology 17(2): 63-90.

21. Brodie G, Pchelnikov Y, Torgovnikov G (2020) Development of microwave slow-wave comb applicators for soil treatment at frequencies 2.45 and $0.922 \mathrm{GHz}$ (theory, design, and experimental study). Agriculture $10(12)$ : 604.

22. Brodie G, Torkovnikov G, Farrell P (2016) Microwave application method and apparatus. Australia Patent.

23. Davis FS, Wayland JR, Merkle MG (1971) Ultrahigh-frequency electromagnetic fields for weed control: phytotoxicity and selectivity. Science 173(3996): 535-537.
24. Davis F (1975)" Zapper" blasts weed seeds. New Zealand Journal of Agriculture.

25. Brodie G, Harris G, Pasma L, Travers A, Leyson D, et al. (2009) Microwave soil heating for controlling ryegrass seed germination. American Society of Agricultural and Biological Engineers 52(1): 295-302.

26. Brodie G, Hollins E (2015) The effect of microwave treatment on ryegrass and wild radish plants and seeds. Global Journal of Agricultural Innovation, Research \& Development 2(1): 16-24.

27. Brodie G, Grixti M, Hollins E, Cole M (2015) The effect of microwave soil treatment on key soil biota. Presented at the $1^{\text {st }}$ URSI Atlantic Radio Science Conference, Canary Islands, Spain.

28. Cooper AP, Brodie G (2009) The effect of microwave radiation and soil depth on soil $\mathrm{pH}, \mathrm{N}, \mathrm{P}, \mathrm{K}, \mathrm{SO}_{4}$ and bacterial colonies. Plant Protection Quarterly 24(2): 67-70.

29. Vela GR, Wu JF, Smith D (1976) Effect of 2450MHz microwave radiation on some soil microorganisms in situ. Soil Science 121(1): 44-51.

30. Khan MJ, Jurburg SD, He J, Brodie G, Gupta D (2019) Impact of microwave disinfestation treatments on the bacterial communities of no-till agricultural soils. European Journal of Soil Science 71(6): 1006-1017.

31. Hendricks CW, Pascoe N (1988) Soil microbial biomass estimates using 2450MHz microwave irradiation. Plant Soil 110(1): 39-47.

32. Khan MJ, Brodie GI (2018) Microwave weed and soil treatment in rice production. In: Shah, Khan, et al. (Eds.), Rice Crop-Current Development. In Tech, Austria, pp. 99-127.

33. Khan MJ, Brodie GI, Gupta D, He J (2019) Microwave soil treatment increases soil nitrogen supply for sustained wheat productivity. Transactions of the ASABE 62(2): 355-362. 